\title{
Efek Pembukaan Lahan terhadap Karakteristik Biofisik Gambut pada Perkebunan Kelapa Sawit di Kabupaten Bengkalis
}

\author{
Suwondo $^{\left.1^{*}\right)}$,Supiandi Sabiham ${ }^{2)}$, Sumardjo ${ }^{2)}$ dan Bambang Paramudya ${ }^{2)}$ \\ ${ }^{1)}$ Program Studi Pendidikan Biologi, Universitas Riau, Pekanbaru 28293 \\ ${ }^{2)}$ Program Studi Pengelolaan Sumberdaya Alam dan Lingkungan, Institut Pertanian Bogor, Bogor 16680 \\ Diterima 20-03-2011 Disetujui 04-07-2011
}

\begin{abstract}
Oil palm plantations at peatland are faced with problems of land degraded, low productivity and produced to green house gas (GRG) emission. The objectives of this study were to land clearing effect of peatlands and to identified factors that affect the peatlands in the biophysical characteristics. This study was conducted on District Bengkalis-Riau at marine and brakish peat. The data was collected using field survey and documentation. The descriptive analysis was used to determine biophysical characteristics and linier regresion was used to corelation perform important factors. The research results showed that the biophysical characteristics of peatland experienced changes in the horizon profile, peat thickness, decomposition level, moisture content, ash content, $\mathrm{pH}$, C-organic and biomass. The secondary peat swamp forest of biophysical characteristics have to different in the horizon profile, peat thickness, decomposition level, moisture content, ash content, $\mathrm{pH}$, $\mathrm{C}$-organic and biomass compared with marine and brackish peat.
\end{abstract}

Keywords: biophysical characteristics, land clearing, peatland, oil palm plantations

\begin{abstract}
ABSTRAK
Pengembangan kelapa sawit pada lahan gambut dihadapkan pada permasalahan degradasi lahan, produktivitas rendah dan potensi emisi gas rumah kaca (GRK). Penelitian ini bertujuan untuk menganalisis perubahan karakteristik biofisik lahan gambut akibat aktivitas pembukaan lahan perkebunan kelapa sawit. Lokasi penelitian berada dalam wilayah Kabupaten Bengkalis Propinsi Riau pada dua tipe fisiografi lahan gambut yakni gambut pantai dan gambut transisi. Pengumpulan data dilakukan dengan menggunakan metode survey dan dokumentasi. Analisis data karakteristik biofisik dilakukan secara deskriptif dan hubungan antar faktor dengan regresi liner. Hasil penelitian menunjukkan bahwa aktivitas perkebunan kelapa sawit dapat merubah karakteristik biofisik lahan gambut. Kandungan C-organik dan kadar air semakin menurun, sedangkan muka air tanah, $\mathrm{pH}$ dan kadar abu semakin meningkat. Karakteristik biofisik hutan rawa gambut sekunder mempunyai perbedaan tingkat dekomposisi, kadar air, kadar abu, pH, C-organik dan biomassa dibandingkan dengan fisiografi lahan gambut pantai dan transisi.
\end{abstract}

Kata kunci: karakteristik biofisik, lahan gambut, pembukaan lahan, perkebunan kelapa sawit

\section{PENDAHULUAN}

Lahan gambut merupakan salah satu tipe ekosistem yang terbentuk pada kondisi anaerob (drainase buruk) di rawa pasang surut atau lebak dan mengandung bahan organik (> 50\%) dari hasil akumulasi sisa tanaman. Lahan gambut memberikan beberapa pelayanan (services) ekologi, ekonomi dan sosial yang potensial untuk dikembangkan sebagai sistem pendukung kehidupan (life supporting system) (Galbraith et al. 2005).

Luas lahan gambut di Indonesia diperkirakan 20,6 juta ha dan 4,1 juta ha di Provinsi Riau. Pemanfaatan lahan gambut untuk perkebunan mencapai 817.593 ha dari total luas perkebunan yang mencapai 2,6 juta ha. Sedangkan

\footnotetext{
*Telp: +628127512108

e-mail: wondo_su@yahoo.co.id
}

luas lahan gambut di Kabupaten Bengkalis mencapai 856.386 ha dengan luas areal perkebunan mencapai 102.858,5 ha (Dinas Perkebunan Provinsi Riau 2009).

Alih fungsi lahan hutan menjadi perkebunan kelapa sawit pada ekosistem rawa gambut merupakan faktor dominan yang menyebabkan terjadinya degradasi lahan gambut (Riwandi 2003). Aktivitas pembukaan lahan yang kurang memperhatikan karakteristik biofisik lingkungan, menyebabkan lahan gambut mengalami degradasi dan menjadi lahan terlantar (Noorginayuwati et al. 1997; Sutikno et al. 1998 diacu dalam Noor 2001).

Pengembangan kelapa sawit pada lahan gambut juga dihadapkan pada permasalahan potensi emisi $\mathrm{CO}_{2}$ sebagai gas rumah kaca (GRK) (Hooijer et al. 2006), dan hilangnya biodiversitas (Noor 2001; Riwandi 2003). Pembukaan lahan 
pada hutan rawa gambut menjadi perkebunan kelapa sawit pada siklus pertanaman 25 tahun diperkirakan menghasilkan net emisi $\mathrm{CO}_{2}$ rata-rata 41 ton $\mathrm{ha}^{-1}$ tahun $^{-1}$ (Agus et al. 2009). Pada rentang waktu 1990-2007 total emisi CO yang dihasilkan dari degradasi hutan, kebakaran dan dekomposisi gambut di Riau mencapai 3,66 G ton $\mathrm{CO}_{2}$ (WWF 2008).

Pemanfaatan lahan gambut untuk usaha perkebunan di Kabupaten Bengkalis belum mampu menjaga keberlanjutan fungsi ekologis pada ekosistem tersebut. Hal ini terlihat dari degradasi lahan gambut yang terjadi seperti penurunan muka tanah dan kejadian kering tidak balik. Kondisi ini menyebabkan terjadinya kebakaran lahan pada musim kemarau dan banjir pada musim penghujan. Agroekologi perkebunan kelapa sawit merupakan suatu sistem yang sangat kompleks dan dinamis. Dinamika sistem terbentuk dari berbagai interaksi antara vegetasi, siklus hara dan hidrologi (Meiling \& Goh 2008). Perkebunan kelapa sawit di lahan gambut diharapkan dapat menerapkan prinsip ekologis kawasan yang berbasis pada optimalisasi dan kelestarian sumber daya.

Pada kenyataannya, perubahan yang terjadi sering memberikan perubahan yang besar dan menyebabkan hilangnya fungsi ekologis pada lahan gambut tersebut. Aktivitas pembukaan dan pembersihan lahan (land clearing) dan pembuatan saluran (drainase) menyebabkan terjadinya perubahan tata air (hidrologi). Las et al. (2009) menyebutkan bahwa kondisi ini berpengaruh pada terjadinya perubahan tingkat kesuburan lahan, penurunan muka tanah (subsidensi) dan dapat menimbulkan kering tidak balik (irreversibel drying).

Untuk itu, telah dilakukan penelitian guna mengetahui aspek biofisik dan faktor penting yang mempengaruhi perubahan karakteristik biofisik lahan gambut akibat kegiatan pembukaan lahan pada perkebunan kelapa sawit.

\section{BAHANDANMETODE}

Lokasi penelitian berada dalam wilayah Kabupaten Bengkalis Propinsi Riau dengan lokasi utama penelitian di Kecamatan Siak Kecil dan Bukit Batu. Sedangkan sebagai pembanding dilakukan penelitian pada lokasi terpilih di sekitar Kecamatan Siak Kecil dan Bukit Batu (Gambar 1). Penetapan lokasi penelitian dilakukan dengan sengaja (purposive) dengan pertimbangan berada pada kawasan cadangan gambut. Pengamatan dilakukan pada dua tipe fisiografi lahan gambut yakni gambut pantai (marine peat) dan transisi (brackish peat).

Data biofisik lahan gambut diperoleh dari hasil survey lapangan melalui pengukuran parameter secara in situ dan laboratorium. Pengambilan contoh tanah gambut utuh (undisturbed soil samples) pada lahan gambut yang belum dilakukan pembukaan lahan (land clearing). Hal ini dilakukan untuk membandingkan karakteristik biofisik lahan gambut alami dengan perubahan biofisik lahan gambut pada perkebunan kelapa sawit. Pengambilan contoh tanah

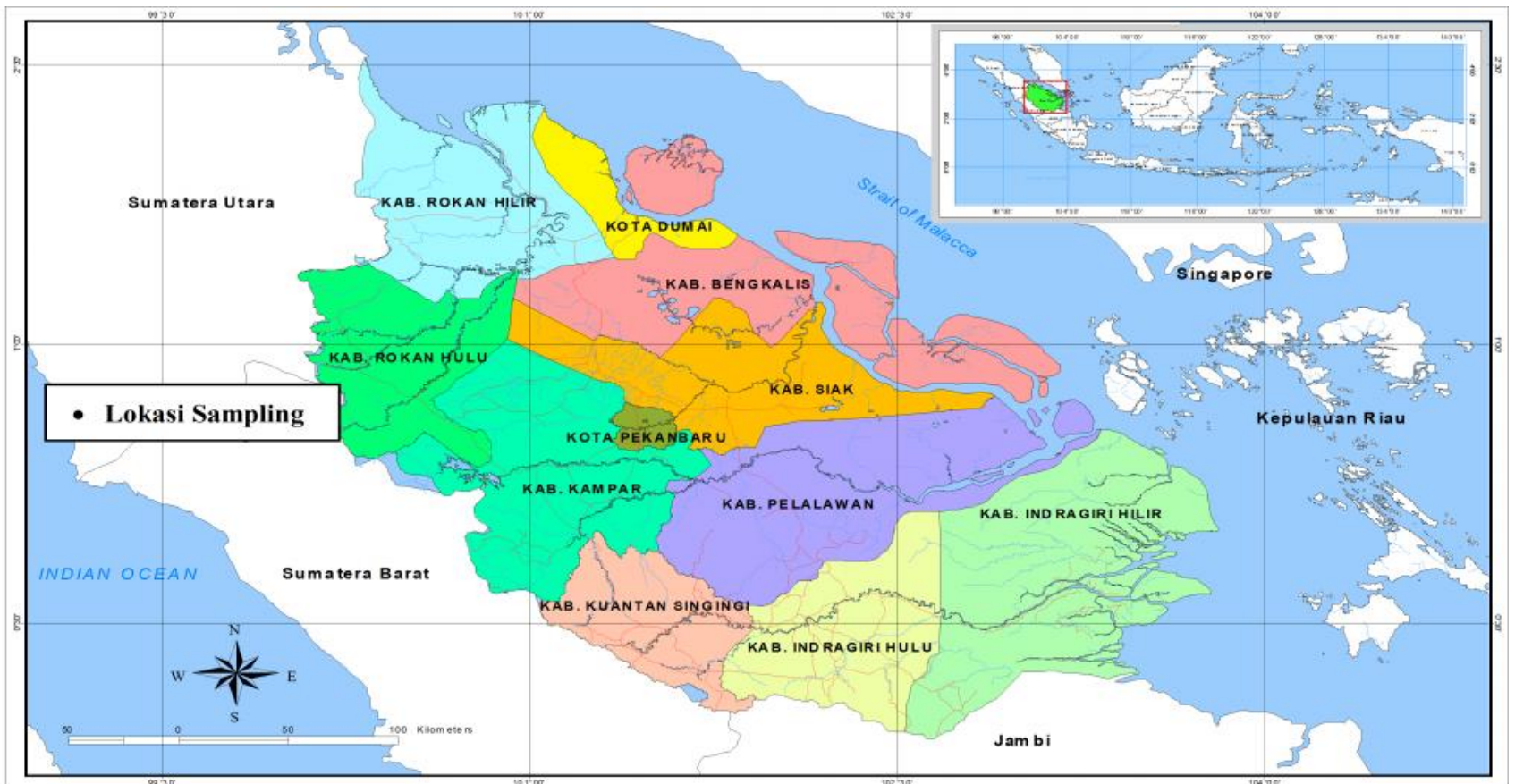

Gambar 1 Peta lokasi sampling lahan gambut di kabupaten bengkalis 
terganggu (disturbed soil samples) pada lahan gambut yang telah dilakukan pembukaan lahan (land clearing). Analisis contoh tanah meliputi warna tanah, kedalaman air tanah, komposisi dan ketebalan gambut, $\mathrm{pH}\left(\mathrm{H}_{2} \mathrm{O}, \mathrm{KCl}\right)$, C-organik (\%), kadar air (\%), kadar abu (\%) dan biomassa tanaman (ton ha' ${ }^{-1}$ ).

Untuk memberi gambaran menyeluruh terhadap kondisi biofisik lahan gambut, pengambilan contoh tanah gambut dilakukan antara lain : (1) pada hutan rawa gambut yang alami (sekunder) dan belum banyak mengalami perubahan biofisik; (2) perkebunan kelapa sawit umur tanam < 3, 3-9 dan $>10$ tahun. Penentuan umur tanaman kelapa sawit dilakukan dengan mempertimbangkan periode (TBM) Tanaman Belum Menghasilkan/< 3 tahun, (TM) Tanaman Menghasilkan dengan periode produksi awal (3-9 tahun) dan periode tanaman menghasilkan pada produksi puncak (> 10 tahun).

Metode analisis warna tanah gambut dengan munsel soil chart, ketebalan gambut $(\mathrm{cm})$ dan kedalaman air tanah $(\mathrm{cm})$ dengan pemboran langsung di lapangan, kematangan/komposisi gambut dengan metode cepat di lapangan (McKinzie). Pengukuran kadar air (\%) dengan metode gravimetri, $\mathrm{pH} \mathrm{H}_{2} \mathrm{O}$ dan $\mathrm{KCl}$ (1:1) dengan $\mathrm{pH}$-meter, C-organik (\%) dengan metode Walkley and Black dan kadar abu (\%) dengan metode gravimetri. Pengukuran biomassa tumbuhan dengan menggunakan metode persamaan alometrik (Brown et al. 1989; Istomo 2002). Karakteristik biofisik lahan gambut dianalisis secara deskriptif dan untuk melihat hubungan antar parameter utama dilakukan analisis regresi-korelasi dengan menggunakan model hubungan logaritmik (Steel \& Torrie 1980).

\section{HASIL DAN PEMBAHASAN}

Aktivitas pembukaan lahan pada hutan rawa gambut menjadi perkebunan kelapa sawit menyebabkan terjadinya perubahan profil horizon pada lahan gambut tersebut. Hal ini terlihat dari perubahan lapisan horizon dan kedalaman serta tingkat kematangan gambut. Perubahan kedalaman horizon hemik menjadi semakin dangkal dengan pertambahan umur perkebunan kelapa sawit (Tabel 1). Kondisi ini disebabkan oleh perubahan tingkat kematangan gambut dari fibrik menuju kondisi hemik dan saprik. Hal ini dapat dilihat dari warna gambut menjadi hitam kemerahan pada lapisan $0-33 \mathrm{~cm}$.

Aktivitas pembukaan lahan pada perkebunan kelapa sawit juga menyebabkan terjadinya perubahan ketebalan gambut, muka air tanah dan kadar air (Gambar 2). Tingkat ketebalan (kedalaman) gambut bervariasi, dimana semakin ke arah kubah gambut (dome) akan semakin meningkat. Berdasarkan fisiografi kedalaman gambut pantai di

Tabel 1 Perubahan profil gambut di perkebunan kelapa sawit

\begin{tabular}{|c|c|c|}
\hline \multicolumn{3}{|c|}{ Hutan Rawa Gambut } \\
\hline \multicolumn{2}{|c|}{ Horizon } & \multirow[t]{2}{*}{ Uraian } \\
\hline Simbol & Kedalaman $(\mathrm{cm})$ & \\
\hline Oe & $0-20$ & Hitam kemerahan (10 R 2.5/1), hemik \\
\hline Oe & $20-50$ & Merah sangat kusam (10 R 2.5/2); hemik \\
\hline Oei & $50-75$ & Merah sangat kusam (10 R 2.5/2); hemik-fibrik \\
\hline $\mathrm{Oi}$ & $75-120$ & Hitam kemerahan - merah sangat kusam (2.5 YR 2.5/1-2); fibrik \\
\hline Oi & $120-480$ & Merah sangat kusam (10 R 2.5/2); -fibrik \\
\hline \multicolumn{3}{|c|}{ Perkebunan Kelapa Sawit Umur $<3$ tahun } \\
\hline \multicolumn{2}{|c|}{ Horizon } & \multirow[t]{2}{*}{ Uraian } \\
\hline Simbol & Kedalaman $(\mathrm{cm})$ & \\
\hline Oe & $0-18$ & Hitam kemerahan (10 R 2.5/1), hemik \\
\hline $\mathrm{Oi}$ & $18-42$ & Hitam kemerahan (2.5 YR 2.5/1); fibrik \\
\hline $\mathrm{Oi}$ & $42-84$ & Merah sangat kusam (2.5 YR 2.5/2); fibrik \\
\hline Ao & $84-106$ & Coklat kemerahan gelap (5YR 2.5/2); liat berdebu, masif \\
\hline A & $>106$ & Kelabu kehijauan terang (10 Y $7 / 2)$, liat; masif \\
\hline \multicolumn{3}{|c|}{ Perkebunan Kelapa Sawit Umur 3- 9 tahun } \\
\hline \multicolumn{2}{|c|}{ Horizon } & \multirow[t]{2}{*}{ Uraian } \\
\hline Simbol & Kedalaman $(\mathrm{cm})$ & \\
\hline Oe & $0-10$ & Coklat kemerahan (5YR 2.5/1), hemik \\
\hline Oi & $10-30$ & Coklat kemerahan gelap (5YR 2.5/2); hemik \\
\hline $\mathrm{Oi}$ & $30-80$ & Hitam kemerahan (10 R 2.5/1); hemik \\
\hline Oi & $80-130$ & Hitam kemerahan (10 R 2.5/1); fibrik \\
\hline Oi & $>130$ & Coklat kemerahan gelap (5YR 3/2); fibrik \\
\hline \multicolumn{3}{|c|}{ Perkebunan Kelapa Sawit > 10 tahun } \\
\hline \multicolumn{2}{|c|}{ Horizon } & \multirow[t]{2}{*}{ Uraian } \\
\hline Simbol & Kedalaman $(\mathrm{cm})$ & \\
\hline $\mathrm{Oa}$ & $0-33$ & Hitam kemerahan (10 R 2.5/1), saprik \\
\hline Ao & $33-43$ & Coklat gelap (7.5 YR 3/2), hemik liat berdebu, masif \\
\hline A1 & $43-100$ & Merah lemah - coklat olive ringan (10 R 5/4 - $2.5 \mathrm{Y} 5 / 3)$, liat, matang \\
\hline $\mathrm{A} 2$ & $>100$ & Kelabu kecoklatan ringan (10 YR 6/2), liat, matang \\
\hline
\end{tabular}


perkebunan sawit berkisar $30-40 \mathrm{~cm}$, gambut transisi antara $44-440 \mathrm{~cm}$ dan hutan rawa gambut $>440 \mathrm{~cm}$.

Semakin lama umur tanam perkebunan sawit akan semakin rendah kadar air pada lahan gambut tersebut. Dimana kondisi ini terjadi pada gambut pantai maupun transisi. Kondisi ini disebabkan oleh perubahan tingkat kematangan (dekomposisi) gambut yang terjadi pada perkebunan sawit tersebut. Noor (2001) menyebutkan bahwa kemampuan menjerap (absorbing) dan memegang (retaining) air dari gambut tergantung pada tingkat kematangannya. Kemampuan menyerap dan mengikat air pada gambut fibrik lebih besar dari gambut hemik dan saprik, sedangkan gambut hemik lebih besar dari saprik.

Ketebalan gambut mempunyai hubungan yang erat dengan kandungan karbon dan penambahan biomassa kelapa sawit (Gambar 3). Hooijer et al. (2006), dan Handayani (2009), menyebutkan bahwa semakin tebal gambut maka kandungan karbon (C) akan semakin meningkat dengan tingkat korelasi yang tinggi $\left(\mathrm{R}^{2}=0,996\right)$. Kedalaman muka air tanah berpengaruh dengan fluks $\mathrm{CO}_{2}$ pada lahan gambut di perkebunan kelapa sawit. Selanjutnya terdapat hubungan yang sangat signifikan $\left(\mathrm{R}^{2}=0,964\right)$ antara pertambahan umur kelapa sawit dengan peningkatan biomassa $\left(\mathrm{t} \mathrm{ha}^{-1}\right)$. Hal ini mengindikasikan bahwa tanaman kelapa sawit dapat menyerap $\mathrm{CO}_{2}$ (carbon sink) yang cukup signifikan. Kondisi ini terlihat pada tanaman kelapa sawit umur $>10$ tahun mempunyai biomassa lebih besar dari hutan rawa gambut sekunder.

Meilling et al. (2005), menyebutkan bahwa alih fungsi lahan gambut untuk kelapa sawit dapat menurunkan emisi $\mathrm{CO}_{2}$. Potensial emisi $\mathrm{CO}_{2}$ dari hutan rawa gambut mencapai $7850 \mathrm{~g} \mathrm{CO}_{2} \mathrm{~m}^{-2}$ tahun $^{-1}$, sedangkan pada perkebunan kelapa sawit mencapai $5706 \mathrm{~g} \mathrm{CO}_{2} \mathrm{~m}^{-2}$ tahun $^{-1}$. Hal ini disebabkan oleh tingginya respirasi tanah pada hutan rawa gambut yang mencapai $7817 \mathrm{~g} \mathrm{CO}_{2} \mathrm{~m}^{-2}$ tahun $^{-1}$, sedangkan pada perkebunan kelapa sawit masing-masing $4074 \mathrm{~g} \mathrm{CO}_{2} \mathrm{~m}^{-2}$ tahun $^{-1}$ dan $5652 \mathrm{~g} \mathrm{CO}_{2} \mathrm{~m}^{-2}$ tahun $^{-1}$. Handayani (2009), menyebutkan bahwa terdapat kecenderungan emisi $\mathrm{CO}_{2}$ akan semakin berkurang dengan pertambahan umur kelapa sawit.

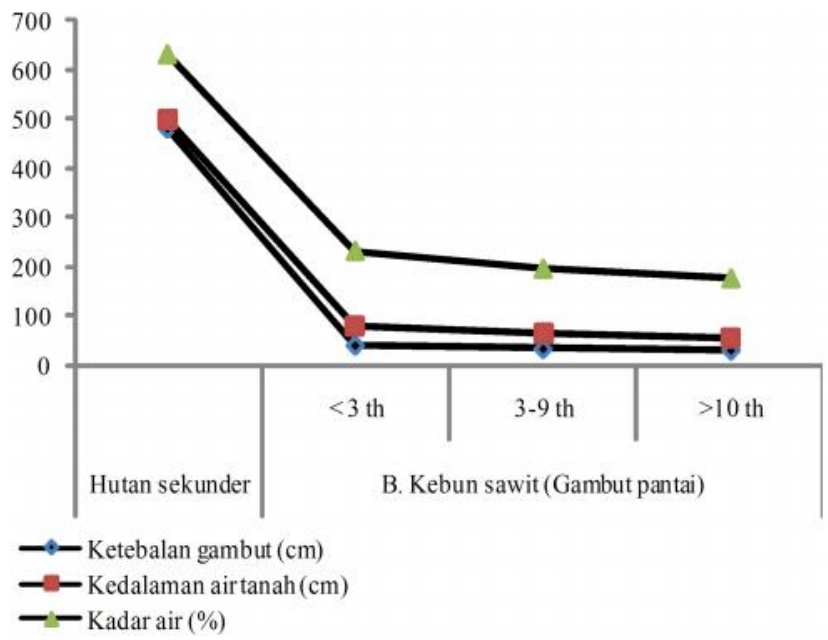

- Kadar air (\%)

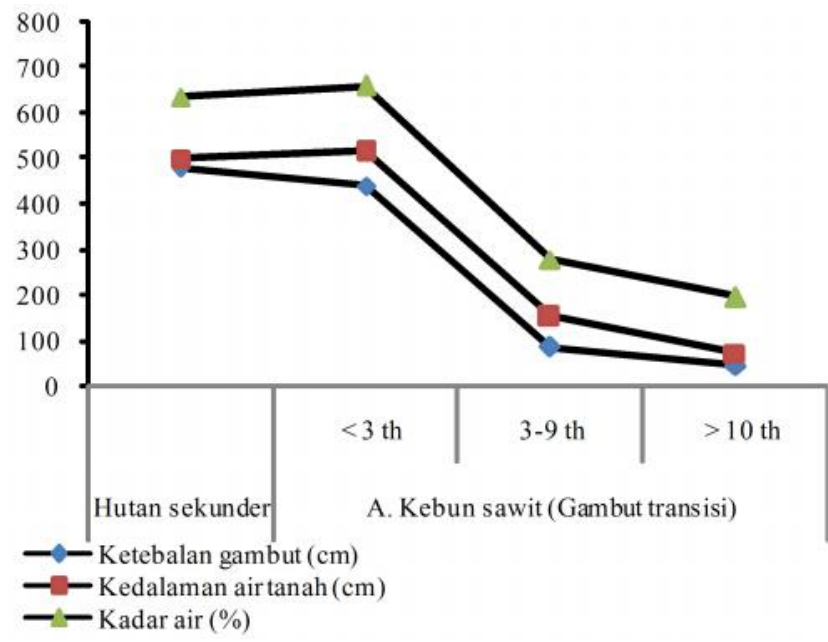

Gambar 2 Karakteristik biofisik pada hutan rawa gambut dan perkebunan sawit (a. Gambut transisi, b. Gambut pantai)

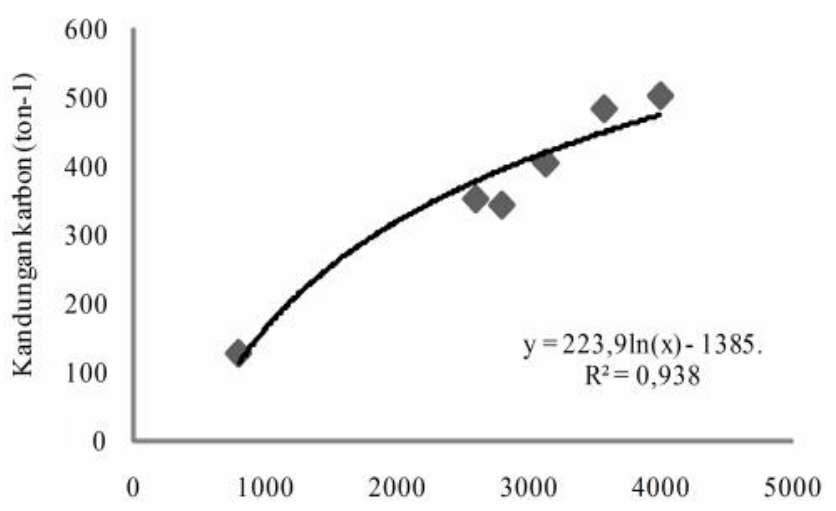

A. Ketebalan gambut $(\mathrm{cm})$

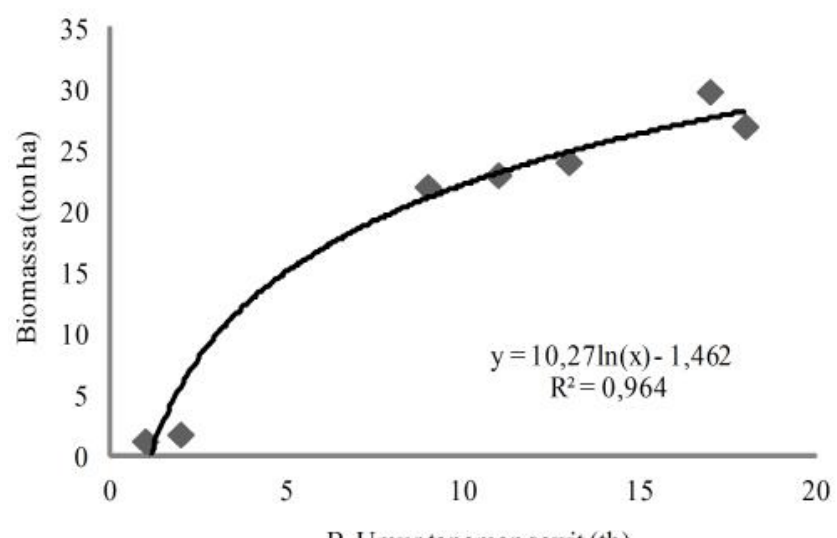

Gambar 3 Hubungan ketebalan gambut dengan kandungan karbon dan umur tanaman sawit dengan peningkatan biomassa 
Pengelolaan kedalaman muka air tanah merupakan kunci dalam pemanfaatan lahan gambut untuk perkebunan kelapa sawit dan usaha untuk melestarikan lingkungan (Handayani 2009; Las et al. 2009). Demikian pemanfaatan lahan gambut untuk perkebunan kelapa sawit dapat diusahakan dengan melakukan pengelolaan tata air yang baik.

$\mathrm{pH} \mathrm{H}_{2} \mathrm{O}$ dan $\mathrm{pH} \mathrm{KCl}$ untuk gambut pantai dan transisi serta pada hutan rawa gambut sekunder mempunyai nilai yang berbeda. Pada gambut pantai $\mathrm{pH}_{2} \mathrm{O}$ pada umur tanam sawit $<3$ tahun: 3,98, umur tanam sawit 3-9 tahun: 4,00 dan umur tanam $>10$ tahun 4,25. Untuk $\mathrm{pH} \mathrm{KCl}$ pada umur tanam sawit $<3$ tahun: 3,25, umur tanam sawit 3-9 tahun: 3,50 dan umur tanam $>10$ tahun: 4,60. Pada gambut transisi nilai $\mathrm{pH}$ $\mathrm{H}_{2} \mathrm{O}$ pada umur tanam sawit $<3$ tahun: 4,03, umur tanam sawit 3-9 tahun: 4,02 dan umur tanam > 10 tahun: 4,10. Untuk $\mathrm{pH} \mathrm{KCl}$ pada umur tanam sawit $<3$ tahun: 3,15, umur tanam sawit 3-9 tahun 3,12 dan umur tanam > 10 tahun: 3,43. Bila dibandingkan nilai $\mathrm{pH}_{2} \mathrm{O}$ di hutan sekunder rawa gambut dengan lahan gambut pantai dan transisi mempunyai nilai $\mathrm{pH}$ yang tidak terlalu berbeda. Sedangkan nilai $\mathrm{pH} \mathrm{KCl}(2,98)$ pada hutan sekunder rawa gambut lebih kecil dibandingkan dengan lahan gambut di perkebunan kelapa sawit. Nilai $\mathrm{pH}$ gambut pada hutan sekunder rawa gambut lebih kecil dibandingkan lahan perkebunan kelapa sawit pada gambut transisi. pH pada lahan gambut transisi lebih rendah dibandingkan gambut pantai. Andriesse (1988), diacu dalam Barchia (2009), menyebutkan bahwa pH gambut yang berada di sekitar kubah (peatdome) lebih rendah dibandingkan dengan gambut yang berada di kawasan pinggir atau mendekati sungai. Hal ini disebabkan oleh adanya pengaruh air sungai atau payau yang mempunyai $\mathrm{pH}$ dan kualitas air

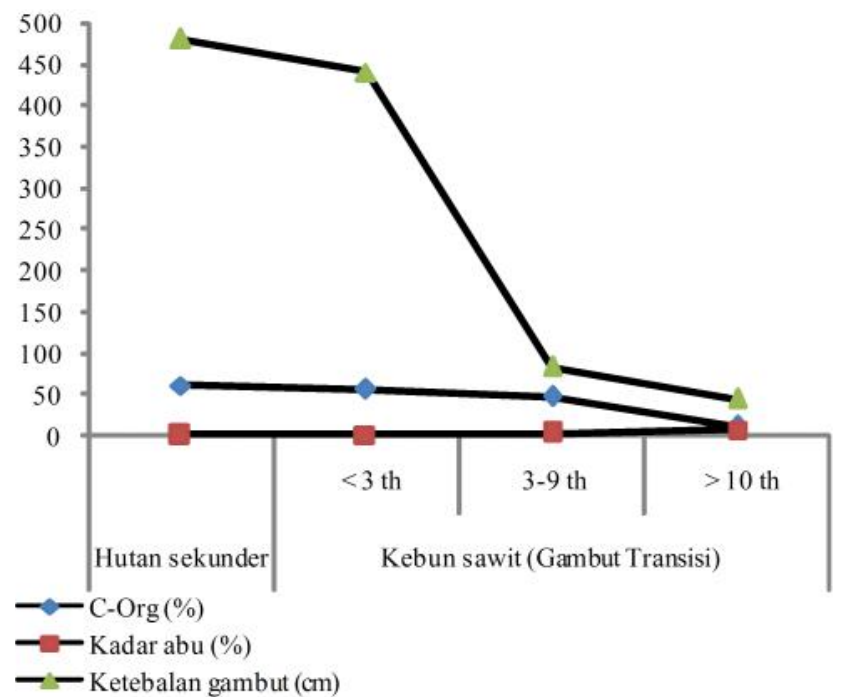

yang lebih baik. Keadaaan ini dapat juga dipengaruhi oleh tingkat ketebalan gambut. Subagyo et al. (1996), menyebutkan bahwa tingkat keasaman gambut dalam relatif lebih tinggi daripada gambut dangkal. Gambut dangkal mempunyai $\mathrm{pH}$ antara 4,0-5,1, sedangkan gambut dalam mempunyai $\mathrm{pH}$ antara 3,1-3,9.

Kandungan C-organik (\%) pada lahan gambut di perkebunan kelapa sawit menunjukkan perbedaan antar umur tanam, fisiografi lahan dan hutan rawa gambut sekunder. Pada perkebunan sawit dengan fisiografi lahan gambut pantai kandungan C-organik berkisar antara 15,49-32,42. Pada lahan gambut transisi kandungan C-organik berkisar antara 11,57-56,95 dan pada hutan rawa gambut 0,87 (Gambar 4). Menurut Barchia (2009), dan Riwandi (2003), kandungan C-organik pada tanah gambut termasuk tinggi berkisar antara 54,3-57,84\%. Sabiham dan Ismangun (1997), menyebutkan bahwa kandungan rata-rata $\mathrm{C}$-organik pada lahan gambut sebesar $57,23 \%$.

Kadar Abu (\%) pada lahan gambut di perkebunan kelapa sawit menunjukkan perbedaan antar umur tanam dan tipe fisiografi lahan serta hutan sekunder rawa gambut. Perkebunan sawit dengan fisiografi lahan gambut pantai kadar abu berkisar antara 43,98-73,23. Pada lahan gambut transisi kadar abu berkisar antara 15,18-79,99 dan pada hutan sekunder rawa gambut 60,95 (Gambar 4). Sabiham dan Ismangun (1997), menyebutkan bahwa kadar abu (\%) pada lahan gambut di Kalimantan Tengah ditemukan sebesar $0,94 \%$ dan di Sumatera Selatan sebesar 5,10\% .

Terdapat hubungan antara kadar abu (\%) dengan Corganik (\%) dan ketebalan gambut (cm) dan kadar abu (\%) pada lahan gambut di perkebunan kelapa sawit (Gambar 5).

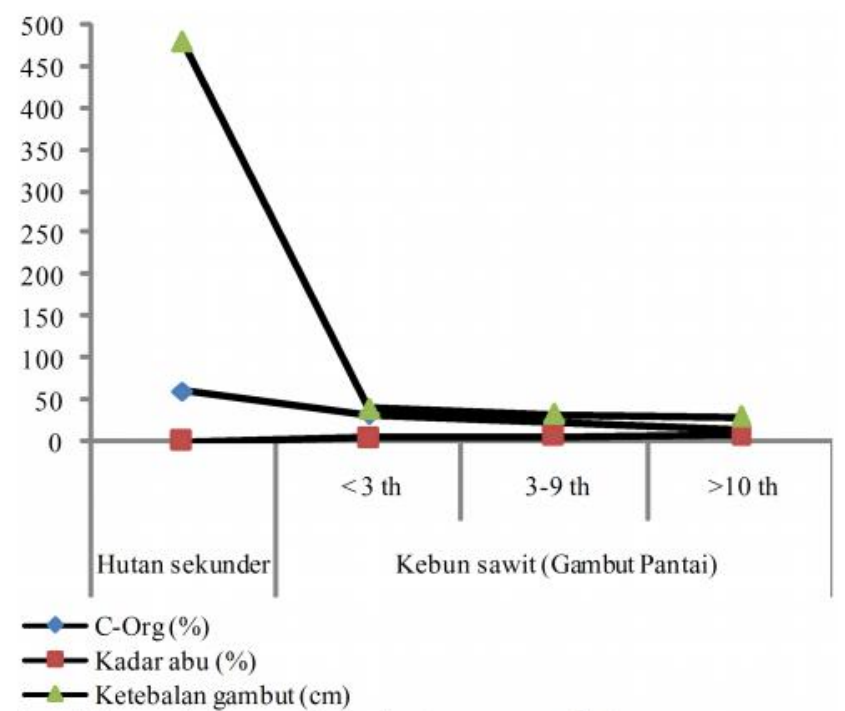

Gambar 4 Kadar C-organik (\%) dan kadar abu (\%) pada lahan gambut di perkebunan kelapa sawit dan hutan rawa gambut 
Kadar C-organik berhubungan negatif dengan kadar abu, dimana semakin tinggi kadar C-organik akan semakin rendah kadar abu $\left(\mathrm{R}^{2}=0,946\right)$ pada lahan gambut di perkebunan kelapa sawit. Sebaliknya semakin tinggi ketebalan gambut pada perkebunan kelapa sawit maka semakin rendah kadar abu $\left(\mathrm{R}^{2}=0,797\right)$. Kadar C-organik juga berhubungan terbalik dengan kadar abu, dimana semakin tinggi kadar C-organik akan semakin rendah kadar abu $\left(\mathrm{R}^{2}=0,98\right)$ pada lahan gambut di perkebunan kelapa sawit.

Biomassa tumbuhan menunjukkan adanya perbedaan antara hutan rawa gambut dengan perkebunan kelapa sawit, baik pada lahan gambut pantai maupun transisi. Pada hutan rawa gambut biomassa ditemukan sebesar 103,28 ton ha-1, perkebunan sawit umur $<3$ tahun 19,85 ton ha-1 ${ }^{-1}$, perkebunan umur 3-9 tahun berkisar antara 26,94 ton ha-1. Pada perkebunan kelapa sawit umur $>10$ tahun ditemukan sebesar 132,63 ton ha ${ }^{-1}$ (Gambar 6).

Biomassa kelapa sawit akan meningkat sejalan dengan bertambahnya umur tanaman, dimana pada umur $>10$ tahun besarnya biomassa sudah menyamai hutan rawa gambut

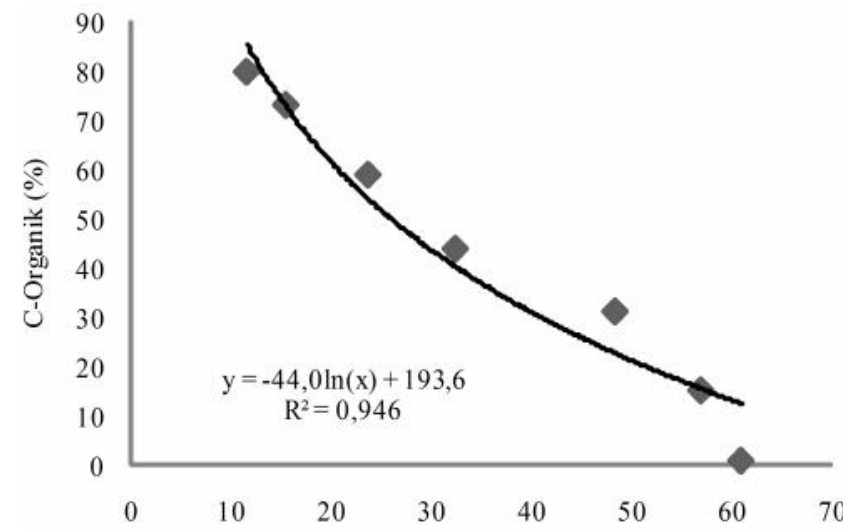

A. Kadar abu (\%)

Gambar 5 Hubungan antara kadar abu (\%) dengan C-organik (\%) dan ketebalan gambut (cm) dan kadar abu (\%) pada lahan gambut

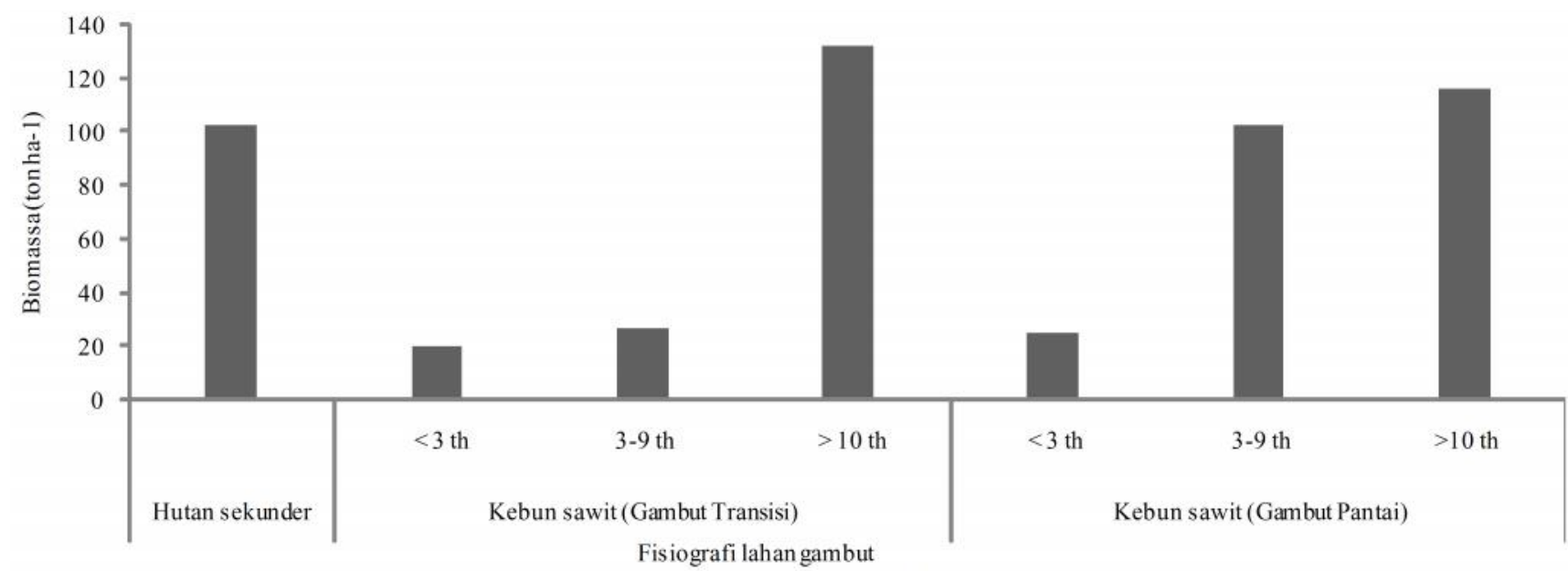

Gambar 6 Perbandingan biomassa $\left(\mathrm{t} \mathrm{ha}^{-1}\right)$ tumbuhan pada hutan rawa gambut sekunder dengan perkebunan kelapa sawit

sekunder (Gambar 6). Corley (1985), diacu dalam Barchia (2009), menyebutkan bahwa laju serapan $\mathrm{CO}_{2}$ oleh tanaman sawit mencapai $3 \mathrm{~g} \mathrm{~m}^{-2} \mathrm{jam}^{-1}$. Produksi biomassa kelapa sawit dapat mencapai 28-30 ton $\mathrm{ha}^{-1}$ pada umur tanaman 6,5-17,5 tahun. Perkebunan sawit di lahan gambut pada umur $>10$ tahun mempunyai biomassa yang lebih besar dari hutan sekunder. Hal ini mengindikasikan kemampuan menyerap karbon yang baik dalam bentuk biomassa tanaman dari perkebunan sawit.

Perubahan karakteristik biofisik lahan gambut disebabkan oleh pembukaan lahan yang menyebabkan terjadinya perubahan tata air (hidrologi) yaitu muka air tanah pada kawasan tersebut. Kondisi ini mempengaruhi tingkat dekomposisi dan merubah karakteristik lahan gambut dibandingkan dengan kondisi alami. Las et al. (2009), dan Sabiham (2007), menyebutkan bahwa pengaturan tata air makro maupun tata air mikro sangat mempengaruhi karakteristik lahan gambut. Tinggi muka air tanah akan mempengaruhi dekomposisi gambut (subsiden) dan kering tak balik (irreversibel drying).

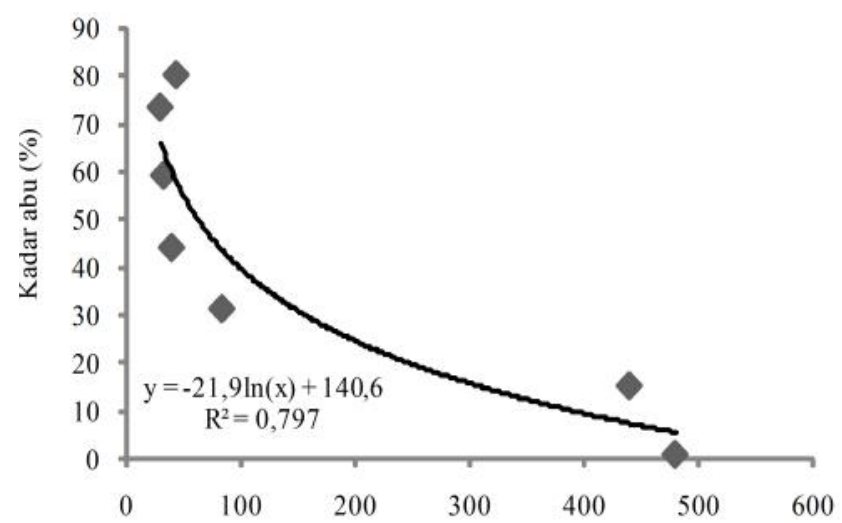

B. Ketebalan gambut $(\mathrm{cm})$ 600 


\section{SIMPULAN}

Aktivitas perkebunan kelapa sawit dapat merubah karakteristik biofisik lahan gambut. Kandungan C-organik dan kadar air semakin menurun, sedangkan muka air tanah, $\mathrm{pH}$ dan kadar abu semakin meningkat. Biomassa kelapa sawit pada umur $>10$ tahun mempunyai biomassa yang lebih besar dari hutan rawa gambut sekunder. Karakteristik biofisik hutan rawa gambut sekunder mempunyai perbedaan tingkat dekomposisi, kadar air, kadar abu, pH, C-organik dan biomassa dibandingkan dengan fisiografi lahan gambut pantai dan transisi.

\section{UCAPANTERIMAKASIH}

Terima kasih disampaikan kepada kepada Tim Peneliti The Toyota Foundation yang telah memberikan dukungan dana penelitian (Research Grant Program), sehingga kegiatan penelitian yang dilakukan dapat berjalan sesuai dengan rencana dan tahapan yang telah ditetapkan.

\section{DAFTAR PUSTAKA}

Agus, F.E., Runtunuwu, T., June, E., Susanti, H., Komara, I., Las \& van Noordwijk, M. 2009. Carbon budget in land use transitions to plantation. J Penelitian dan Pengembangan Pertanian 29(4): 119-126.

Barchia, M.F. 2009. Agroekosistem Tanah Mineral Masam. Yogyakarta: Gadjah Mada University Press.

Brown, S., Gillespie, A.J.R \& Lugo, A.E. 1989. Biomass estimation methods for tropical forest with application to forest inventory Data. Forest Science 35(4): 881-902.

Dinas Perkebunan Provinsi Riau. 2009. Statistik Perkebunan Riau. Pekanbaru.

Galbraith, H., Amerasinghe, P \& Lee, H.A. 2005. The effects of Agricultural Irrigation on Wetland Ecosystems in Developing Countries: A literature review. CA Discussion Paper 1 Colombo, Sri Lanka: Comprehensive Assessment Secretariat.
Hooijer, A., Silvius, M., Wosten., H \& Page, S. 2006. Peat-CO, Assessment of $\mathrm{CO}_{2}$ Emissions from Drained Peatlands in SE Asia.

Handayani, E.P. 2009. Emisi karbondioksida $\left(\mathrm{CO}_{2}\right)$ dan metan $\left(\mathrm{CH}_{4}\right)$ pada perkebunan kelapa sawit di lahan gambut yang memiliki keragaman dalam ketebalan gambut dan umur tanaman. Disertasi: Bogor. Institut Pertanian Bogor.

Istomo. 2002. Kandungan Fosfor dan Kalsium serta Penyebarannya Pada Tanah dan Tumbuhan Hutan Rawa Gambut. Disertasi Program Pascasarjana. Bogor: IPB.

Las, I..K., Nugroho \& Hidayat, A. 2009. Strategi Pemanfaatan Lahan Gambut Untuk Pengembangan Pertanian Berkelanjutan. Balai Besar Penelitian dan Pengembangan Sumberdaya Lahan Pertanian. Bogor. J Pengembangan Inovasi Pertanian 2(4): 295-298.

Meiling, L \& Goh, K.J. 2008. Sustainable oil Palm cultivation on tropical peatland. Kualalumpur: Trofical Peat Research Laboratory and Applied Agricultural Resources.

Melling, L., Hatano, R \& Goh, K.J. 2005. Soil CO2 flux from three Ecosystems in Tropical Peatland of Sarawak. Malaysia: Tellus B 57(1): 1-11.

Noor, M. 2001. Pertanian Lahan Gambut; Potensi dan Kendala. Yogyakarta: Kanisius.

Riwandi. 2003. Indikator stabilitas gambut berdasarkan analisis kehilangan karbon organik, sifat fisikokimia dan komposisi bahan gambut. Jurnal Penelitian UNIB 9(1): 25-36.

Sabiham S. 2007. Pengembangan lahan secara berkelanjutan sebagai dasar dalam pengelolaan gambut di Indonesia. Makalah Utama Seminar Nasional Pertanian Lahan Rawa. Kapuas 3-4 Juli 2007.

Sabiham, S \& Ismangun, M. 1997. Potensi dan kendala pengembangan lahan gambut untuk pertanian. Proseding Simposium Nasional dan Konggres V PERAGI. Jakarta, 25-27 Januari 1996.

Steel, R.G.D \& Torrie, J.H. 1980. Analysis of covariance, In: Principles and Procedures of Statistics: a Biometrical Approach, New York: McGraw-Hill.

Subagyo, H., Marsoedi \& Karama, A.S. 1996. Prospek pengembangan lahan gambut untuk pertanian; Seminar Pengembangan Tehnologi Berwawasan Lingkungan Untuk Pertanian Pada Lahan Gambut. Dalam Rangka Peringatan Dies Natalis ke 33 Bogor: IPB Tgl 26 September 1996.

[WWF] Word Wild Found. 2008. How Pulp \& Paper and Palm Oil from Sumatra Increase Global Climate Change and Drive Tigers and Elephants to Local Extinction. WWF Indonesia Technical Report. 